\title{
CHEMICAL TREATMENT OF BANANA TREE PSEUDOSTEM PARTICLES AIMING THE PRODUCTION OF PARTICLEBOARDS
}

\author{
Tratamento químico de partículas de pseudocaule de bananeira \\ visando à produção de painéis aglomerados
}

\author{
Bárbara Maria Ribeiro Guimarães ${ }^{1}$, Lourival Marin Mendes $^{2}$, Gustavo Henrique Denzin Tonoli², \\ Lina Bufalino², Rafael Farinassi Mendes ${ }^{2}$, José Benedito Guimarães Junior ${ }^{3}$
}

\begin{abstract}
Brazil is one of the major banana producers in the world, and consequently generates a great amount of residues from this crop, which could be utilized in particleboard production. The present work aimed to evaluate the effect of different chemical treatments of the particles of Musa sp. pseudostem, on their chemical and physical properties (basic density), and on the physical and mechanical properties of the particleboards produced with the same material. Five treatments were applied to the particles: 1) without treatment (control); 2) $2 \%$ acetic acid; 3$) 0.5 \% \mathrm{NaOH}$; 4 ) acetone (1/1 in volume/volume); and 5) water. Panels with medium density were produced $\left(0.70 \mathrm{~g} / \mathrm{cm}^{3}\right)$, bonded with $12 \%$ (in relation to the particle mass) of urea-formaldehyde adhesive. The pressing cycle was conducted at $160^{\circ} \mathrm{C}$, under $4 \mathrm{MPa}$, during $8 \mathrm{~min}$. The results obtained indicated that the chemical treatments performed in the particles of banana tree pseudostem affected their chemical composition. The basic density of the particles was $0.10 \mathrm{~g} / \mathrm{cm}^{3}$, and only the $\mathrm{NaOH}$ treatment led to its increase for values around $0.13 \mathrm{~g} / \mathrm{cm}^{3}$. The panels produced with particles without treatment (control) and particles treated with acetic acid presented the lowest values of water absorption and thickness swelling after 2 and $24 \mathrm{~h}$ of immersion. Mechanical properties of all the panels produced were below the minimum recommended by the standard CS 236-66 (COMMERCIAL STANDARD - CS, 1968).
\end{abstract}

Index terms: Musa sp., lignocellulosic residues, chemical treatments.

\begin{abstract}
RESUMO
O Brasil é um dos maiores produtores de banana do mundo e, consequentemente, gera uma grande quantidade de resíduos provenientes dessa cultura, os quais poderiam ser aproveitados na produção de aglomerados. No presente trabalho, objetivou-se avaliar o efeito de diferentes tratamentos químicos nas partículas de pseudocaule da bananeira Musa sp. em suas propriedades químicas e físicas (densidade básica), além da influência desses tratamentos nas propriedades físicas e mecânicas de painéis aglomerados produzidos com o mesmo material. Foram realizados 5 tratamentos nas partículas, sendo: 1) sem tratamento (testemunha); 2) ácido acético $2 \% ; 3) \mathrm{NaOH} 0,5 \%, 4)$ acetona ( $1 / 1$ em volume/volume); e 5) água. Os painéis produzidos foram de média densidade (0,70 $\mathrm{g} / \mathrm{cm}^{3}$ ), encolados com o adesivo ureia-formaldeído a $12 \%$ (em relação à massa de partículas). $\mathrm{O}$ ciclo de prensagem utilizado foi 4 $\mathrm{MPa}$ de pressão, a uma temperatura de $160^{\circ} \mathrm{C}$, por um período de $8 \mathrm{~min}$. Os resultados obtidos indicaram que todos os tratamentos químicos realizados nas partículas de pseudocaule da bananeira afetaram a composição química do material. A densidade básica das partículas do pseudocaule foi de $0,10 \mathrm{~g} / \mathrm{cm}^{3}$ e o tratamento com $\mathrm{NaOH}$ foi o único que afetou essa propriedade, ocasionando seu aumento para $0,13 \mathrm{~g} / \mathrm{cm}^{3}$. Os painéis produzidos com as partículas sem tratamento (testemunha), e com as tratadas com ácido acético foram os que apresentaram menores valores de absorção de água e inchamento em espessura após 2 e 24 h de imersão. As propriedades mecânicas de todos os painéis produzidos ficaram abaixo do mínimo recomendado pela norma CS 236-66 (COMMERCIAL STANDARD - CS, 1968).
\end{abstract}

Termos para indexação: Musa sp., resíduos lignocelulósicos, tratamentos químicos.

\section{INTRODUCTION}

The expansion of Brazilian crops was very important for the country's economy in the last decade. As a consequence, a great number of waste residues were produced and some of them with enormous potential for industrial products (Barros Filho et al., 2011). In Brazil, the industry of particleboards consumes a significant volume of wood from planted forests, mainly from Pinus and Eucalyptus genera. In order to attend the increasingly demand for wood, it is necessary to increase the planted area with such species and to search for raw materials from alternative fast-growing species. The utilization of residues generated by the Brazilian agribusiness may be considered an alternative for the particleboard sector. Among the potential raw materials, it may be mentioned:

\footnotetext{
1Universidade Federal de Lavras/UFLA - Departamento de Ciências Florestais/DCF - Cx. P. 3037-37200-000-Lavras-MG-Brasil-bmrg2115@yahoo.com.br 2Universidade Federal de Lavras/UFLA - Departamento De Ciências Florestais/DCF - Lavras - MG - Brasil

3Universidade Federal de Goiás/UFGO - Departamento de Ciências Florestais/ DCF - Goiânia - GO - Brasil

Receinved in april 20, 2013 and approved in november 29, 2013
} 
corncob, rice, coffee, coconut and peanut husks, cassava and mammon stem, sugarcane bagasse and banana tree pseudostem (Mendes et al., 2010).

Brazil is the fifth larger banana producer in the world, with a planted area of 4.8 million of hectares (Food and Agricultural Organization of United-FAO, 2013; Empresa Brasileira de Pesquisa Agropecuária-EMBRAPA, 2011). One of the problems in the management of banana crop is the waste disposal. Each hectare of banana crop generates around $220 \mathrm{t}$ of plant residues that consists mainly of lignocellulosic fibrous materials (Reedy, 2003). The wastes are usually used as raw material for pulp production and papermaking, as source for energy generation or as handicrafts (Rojas, 1996).

The low elasticity modulus and high water absorption are the main drawbacks to the use of lignocellulosic materials in all kinds of particleboards. If the lignocellulosic particles are not modified, they may be attacked by fungi and insects, besides presenting a great variability of properties among individuals of the same species (Ghavami; Tolêdo Filho, 1992). Some proposals are presented aiming to minimize dimensional instability problems of plant fibrous materials through chemical modification (Okino; Rowell, 1996; Guiotoku et al., 2008). However, there is a lack of information on the efficiency of chemical modifications of banana pseudostem particles in order to improve physical and mechanical properties of particleboards. This work aimed to verify the feasibility of applying different chemical modifications in banana pseudostem particles as strategy for improvement of the performance of the ensuing particleboards.

\section{MATERIAL AND METHODS}

\section{Raw material and treatment of the lignocelulosic particles}

The particles were obtained from banana tree (Musa sp.) pseudostems collected at the Federal University of Lavras, latitude $21^{\circ} 14^{\prime} \mathrm{S}$, longitude $45^{\circ} 00 \mathrm{~W}$ and around $900 \mathrm{~m}$ high.

The pseudostems were manually de-fibrillated and dried at room conditions (at around $25^{\circ} \mathrm{C}$ and $70 \%$ $\mathrm{RH})$. Afterwards, the material was transformed into sliver particles in a hammer mill. The particles retained in a sieve with $2.2 \mathrm{~mm}^{2}$ apertures were selected for board production. Five chemical treatments were used for the particles: 1) without treatment (control - dried until 3\% of moisture content);2) immersion in $2 \%$ acetic acid solution; 3 ) immersion in $0.5 \%$ sodium hydroxide solution; 4) acetone solution at 1:1 ratio (in volume); and 5) water. The immersion time for all treatments was $24 \mathrm{~h}$. The particles were washed under continuous water flow for chemical removal and dried at room conditions (at around $25^{\circ} \mathrm{C}$ and $70 \% \mathrm{RH}$ ) during 15 days. Before board production they were kiln-dried at $100^{\circ} \mathrm{C}$ until $3 \%$ of moisture content.

\section{Chemical and physical characterization of the lignocellulosic material}

Samples were removed from different pseudostem heights $(0,25,50,75$ and $100 \%)$. These samples were milled and mixed together in order to be used for all chemical and physical analyses and for particleboards production. Total extractives content was determined based on the Associação Brasileira de Normas Técnicas-NBR 14853 (2010a) standard, while lignin and ash contents were obtained in accordance with NBR 7989 (2010b) and NBR 13999 (2003) standards, respectively. The holocellulose content was determined by Equação.(1):

$$
\begin{aligned}
& \text { Holocellulose }(\%)=100(\%)-\text { Extractives }(\%) \\
& \text { - Lignin }(\%)-\text { Ash }(\%)
\end{aligned}
$$

Basic density of the treated and non-treated fibrous particles was determined according to the methodology described by Vital (1984).

\section{Panels manufacture}

The sliver particles were dried until 3\% of moisture content, previously to the particleboard production. Urea-formaldehyde adhesive was applied at $12 \%$ of solids (in relation to particle mass) using a rotatory drum blender. Previous laboratory studies demonstrated that lower adhesive contents did not result in suitable particle bonding. Panels were produced with the target density of $0.70 \mathrm{~g} / \mathrm{cm}^{3}$.

The lignocellulosic particles were deposited in a mat-forming box with dimensions of $480 \mathrm{~mm} \times 480$ $\mathrm{mm}$ (width and length of the final panels). Pre-pressing was performed in a manual press in order to improve the contact among particles. The hot pressing was performed in a hydraulic press, until boards become with $15 \mathrm{~mm}$ thickness. The pressing cycle was done at $160^{\circ} \mathrm{C}$ for 8 min under $4 \mathrm{MPa}$. Panels were cut in a circular saw, and the specimens were stacked and kept in an acclimatized room at $22 \pm 2{ }^{\circ} \mathrm{C}$ and $65 \pm 5 \% \mathrm{RH}$ until constant mass, before the physical and mechanical tests.

The dimensions of the specimens and the procedures applied on the evaluation of water absorption (WA) and thickness swelling (TS) after 2 and $24 \mathrm{~h}$ of immersion, and internal bond, were defined based on the American Society 
For Testing And Materials-ASTM D1037 (2006) standard. NBR14810 (2002) standard was used for determination of the panel density. The static bending was used for determination of modulus of rupture (MOR) and modulus of elasticity (MOE) following the Normem Fur Holzf Aserplaten-DIN 52362 (1982) standard.

The sampling design was entirely randomized, and composed by the different chemical treatments of the particles. Variance analysis and Scott-Knott test at $5 \%$ of significance were performed using the SISVAR software for comparisons among the treatments.

\section{RESULTS AND DISCUSSION}

\section{Chemical and physical analysis}

Table 1 depicts the chemical components and basic density of the particles obtained from banana tree pseudostem.

All treatments removed significantly the extractives. In general, extractives are easily isolated in water or organic solvents (Sjöström; Alén, 1998; Gullichsen; Paulapuro, 2000). Extractives may influence adhesive curing by turning weaker the adhesive-particle bond, and hence resulting in low strength of the produced panels (Marra, 1992).

The $\mathrm{NaOH}$ treatment caused the significant decrease of the lignin content. It is well know that the $\mathrm{NaOH}$ treatment removes partially the lignin and hemicelluloses (Fengel; Wegener, 1989). Lignin is a natural adhesive that can contribute to improve the adhesion between the particles in the panel, resulting in an improved bonding and dimensional stability (Joseleau et al., 2004; Khedari et al., 2004).

The chemical treatments led to significant changes in the holocellulose content, which is associated to the changes in the contents of the other components (extractives, lignin and ash).
The average basic density for the banana tree pseudostem particles was $0.100 \pm 0.005 \mathrm{~g} / \mathrm{cm}^{3}$. This result is lower than the observed by Savastano Junior and Pimentel (2000), who found $0.170 \mathrm{~g} / \mathrm{cm}^{3}$ for the same species. Such variability in density for the same species may be attributed to environmental or genetic factors and to the age of the individuals. The density found for the raw banana tree pseudostem particles is lower than the determined for the jute and mallow stem, which ranged between 0.270 and $0.335 \mathrm{~g} / \mathrm{cm}^{3}$ (Azzini; Benatti Jr; Arruda, 1986) for the first, and around $0.254 \mathrm{~g} / \mathrm{cm}^{3}$ for the former (Savastano Junior; Pimentel, 2000); and close to the determined for sugarcane cob, which was around $0.098 \mathrm{~g} / \mathrm{cm}^{3}$ (Mendes et al., 2010).

\section{Physical and mechanical properties of the particleboards}

The values of apparent density obtained for the panels ranged from 0.61 to $0.67 \mathrm{~g} / \mathrm{cm}^{3}$ and there was no significant difference among them $(\mathrm{p}<0.05)$. According to the NBR 14810-2 (2002) standard, these panels are classified as medium density particleboards (from 0.551 $\mathrm{g} / \mathrm{cm}^{3}$ to $\left.0.750 \mathrm{~g} / \mathrm{cm}^{3}\right)$.

\section{Water absorption and thickness swelling}

The results of WA and TS after 2 and $24 \mathrm{~h}$ of immersion are presented in table 2. Panels made with particles treated with $\mathrm{NaOH}$ presented the highest values of WA and TS for 2 and $24 \mathrm{~h}$ of immersion. Panels made with non-treated particles and particles treated with acetic acid presented the lowest TS values.

The poor resistance to water absorbance found for particleboards with $\mathrm{NaOH}$ treated particles may be partially attributed to the lower lignin content, which is a hydrophobic component. This chemical treatment also causes swelling of the cellulose crystalline structure, which may facilitate water entrance (Sellers; Mcsween Jr; Nearn, 1988; Joseleau et al., 2004; Khedari et al., 2004; John; Anandjiwala, 2008).

Table 1- Chemical components and basic density of the banana tree pseudostem.

\begin{tabular}{lccccc}
\hline Particle treatments & Extractives (\%) & Lignin (\%) & Ashes (\%) & Holocellulose (\%) & Basic density $\left(\mathrm{g} / \mathrm{cm}^{3}\right)$ \\
\hline Control & $18.6 \mathrm{~A}$ & $15.7 \mathrm{~A}$ & $13.8 \mathrm{~A}$ & $51.9 \mathrm{~B}$ & $0.100 \mathrm{~B}$ \\
Acetic acid & $14.2 \mathrm{~B}$ & $14.8 \mathrm{~A}$ & $9.9 \mathrm{D}$ & $61.2 \mathrm{~A}$ & $0.089 \mathrm{~B}$ \\
$\mathrm{NaOH}$ & $13.5 \mathrm{~B}$ & $11.6 \mathrm{~B}$ & $14.3 \mathrm{~A}$ & $60.6 \mathrm{~A}$ & $0.134 \mathrm{~A}$ \\
Acetone & $11.5 \mathrm{~B}$ & $16.2 \mathrm{~A}$ & $12.7 \mathrm{~B}$ & $59.6 \mathrm{~A}$ & $0.108 \mathrm{~B}$ \\
Water & $11.8 \mathrm{~B}$ & $16.4 \mathrm{~A}$ & $11.5 \mathrm{C}$ & $60.3 \mathrm{~A}$ & $0.103 \mathrm{~B}$ \\
\hline $\mathrm{CV}(\%)$ & 7.7 & 2.3 & 2.1 & 1.6 & 13.7 \\
\hline
\end{tabular}

* Means followed by the same letter do not differ significantly by the Scott-Knott test at 5\%. 
Moreover, it should be noticed that the cure of the urea-formaldehyde adhesive occurs in acid conditions (Pizzi, 1994), which could be hindered by the $\mathrm{NaOH}$ treatment. Similar results of water resistance between particles treated with acetic acid and without treatments corroborates this fact, considering that an adequate cure was achieved by using acid treated particles. In addition, the treatment with acetic acid may modify the hydroxyl groups at the particle surface (Cabral et al., 2006), reducing interaction between particle and water (Okino et al., 1987; Cabral et al., 2006).

The CS 236 (1968) standard for medium density particleboards produced with urea-formaldehyde adhesive establishes that the thickness swelling after $24 \mathrm{~h}$ of immersion must be below 35\%. Thereby, only the panels made with banana tree pseudostem particles without treatment and with particles treated with acetic acid met the standard requirements.

\section{Mechanical properties}

Average values of mechanical properties of the particleboards are presented in table 3 .
Significant differences for MOR and MOE were not observed among the treatments. The values observed in this work were lower than the established by the CS 236-66 (1968) standard for particleboards with density between 0.60 and $0.80 \mathrm{~g} / \mathrm{cm}^{3}$, which establishes minimum mean values of 11.2 MPa for MOR and 2454.9 MPa for MOE.

Except for acetone, the chemical treatments decreased the internal bond strength in relation to the panel done with particles without treatment (control). The CS 236-66 (1968) standard for medium density particleboards bonded with urea-formaldehyde, establishes the minimum value of $0.43 \mathrm{MPa}$ for internal bond of the panels. Therefore, none of the treatments attended the standard requirements. The low content of lignin found for the pseudostem particles after the treatment with $\mathrm{NaOH}$ may have contributed to the low adhesion among particles and consequently low values of internal bonding.

The values of compression strength ranged from 2.57 to $3.87 \mathrm{MPa}$. It was observed that the treatments with $\mathrm{NaOH}$ and acetone did not result in significant

Table $2-$ WA and TS after 2 and $24 \mathrm{~h}$ of immersion.

\begin{tabular}{lcccc}
\hline \multirow{2}{*}{ Particle treatments } & \multicolumn{4}{c}{ Physical properties } \\
\cline { 2 - 5 } & WA 2h (\%) & WA 24 h (\%) & TS 2 h (\%) & TS 24 h (\%) \\
\hline Control & $54.8 \mathrm{~B}$ & $82.5 \mathrm{C}$ & $9.7 \mathrm{C}$ & $15.2 \mathrm{C}$ \\
Acetic acid & $39.8 \mathrm{~B}$ & $85.7 \mathrm{C}$ & $10.6 \mathrm{C}$ & $17.1 \mathrm{C}$ \\
$\mathrm{NaOH}$ & $148.8 \mathrm{~A}$ & $189.8 \mathrm{~A}$ & $55.0 \mathrm{~A}$ & $74.0 \mathrm{~A}$ \\
Acetone & $54.5 \mathrm{~B}$ & $105.6 \mathrm{~B}$ & $21.2 \mathrm{~B}$ & $36.4 \mathrm{~B}$ \\
Water & $70.8 \mathrm{~B}$ & $113.4 \mathrm{~B}$ & $27.9 \mathrm{~B}$ & $40.2 \mathrm{~B}$ \\
\hline $\mathrm{CV}(\%)$ & 28.0 & 10.6 & 23.5 & 18.0 \\
\hline
\end{tabular}

* Means followed by the same letter did not differ significantly by the Scott-Knott test at $5 \%$ of probability.

Table 3 - Average mechanical properties of the panels.

\begin{tabular}{lcccc}
\hline Particle treatments & $\begin{array}{c}\text { MOE } \\
(\mathrm{MPa})\end{array}$ & $\begin{array}{c}\text { MOR } \\
(\mathrm{MPa})\end{array}$ & $\begin{array}{c}\text { Internal bond } \\
(\mathrm{MPa})\end{array}$ & $\begin{array}{c}\text { Compression } \\
(\mathrm{MPa})\end{array}$ \\
\hline Control & $1187 \mathrm{~A}$ & $8.5 \mathrm{~A}$ & $0.20 \mathrm{~A}$ & $3.9 \mathrm{~A}$ \\
Acetic acid & $1004 \mathrm{~A}$ & $8.7 \mathrm{~A}$ & $0.16 \mathrm{~B}$ & $2.9 \mathrm{~B}$ \\
$\mathrm{NaOH}$ & $1128 \mathrm{~A}$ & $8.2 \mathrm{~A}$ & $0.05 \mathrm{C}$ & $3.5 \mathrm{~A}$ \\
Acetone & $1230 \mathrm{~A}$ & $9.7 \mathrm{~A}$ & $0.19 \mathrm{~A}$ & $3.8 \mathrm{~A}$ \\
Water & $1301 \mathrm{~A}$ & $8.9 \mathrm{~A}$ & $0.17 \mathrm{~B}$ & $2.6 \mathrm{~B}$ \\
\hline $\mathrm{CV}(\%)$ & 26.1 & 25.5 & 22.5 & 33.2 \\
\hline
\end{tabular}

* Means followed by the same letter did not differ significantly by the Scott-Knott test at $5 \%$ of probability. 
effect on compression strength, once the results were similar to the panels with particles without treatment (control). The other treatments (acetic acid and water) led to the decrease of such property. Guimarães Júnior et al. (2009) obtained compression values ranging from 5.81 to $6.67 \mathrm{MPa}$ for Eucalyptus cloeziana, from 4.48 to $5.98 \mathrm{MPa}$ for Eucalyptus grandis and from 5.24 to $5.90 \mathrm{MPa}$ for Eucalyptus saligna. Cabral et al. (2007), working with a mix of Eucalyptus spp. and Pinus elliottii particles in the particleboards, found values ranging from 5.68 to $8.0 \mathrm{MPa}$. This is because the use of lignocellusic materials with high lignin content is desirable for the particleboard production, since this component enhances compression strength (Sweet; Winandy, 1999;Bbufalino et al., 2012). However, there are no standards that specify minimum values for compression results of particleboards.

\section{CONCLUSIONS}

The chemical treatments performed here in the particles of banana tree pseudostem affected their chemical composition. The basic density of the material was only affected by the $\mathrm{NaOH}$ treatment.

Panels produced with non-treated particles of banana tree pseudostem and produced with particles treated with acetic acid, reached the requirements of thickness swelling (TS) established for commercialization. However, there was no significant differences for TS between the treatments evaluated. Thereby, raw fibrous particles (without treatment) may be considered the most feasible option for particleboard production.

The mechanical properties of the particleboards produced with non-treated and chemically treated pseudostem particles were below the established by the commercial standard.

In general, the treatments with $\mathrm{NaOH}$, acetone and water used in the present work, showed to be unfeasible for improving the performance of particleboards made with banana tree pseudostem. Such result indicates that is still necessary the modification of the treatment variables used here, such as the immersion time, content and type of chemicals used to adequate the banana tree pseudostem particles for the production of particleboards.

\section{ACKNOWLEDGEMENTS}

The authors acknowledge the support of the Fundação de Amparo à Pesquisa do Estado de Minas Gerais - FAPEMIG, Coordenação de Aperfeiçoamento de Pessoal de Nível Superior - CAPES and Conselho Nacional de Desenvolvimento Científico e Tecnológico
- CNPq. Thanks also to the Brazilian Research Network in Lignocellulosic Composites and Nanocomposites RELIGAR.

\section{REFERENCES}

AMERICAN SOCIETY FOR TESTING AND

MATERIALS. D-1037: standard methods of evaluating properties of wood base fiber and particles materials.

In: Philadelphia, p.1-30, 2006.

ASSOCIAÇÃO BRASILEIRA DE NORMAS TÉCNICAS. NBR 13999: papel, cartão, pastas celulósicas e madeira: determinação do resíduo (cinza) após a incineração a $525^{\circ} \mathrm{C}$. Rio de Janeiro, $4 p ., 2003$.

ASSOCIAÇÃO BRASILEIRA DE NORMAS TÉCNICAS. NBR 14810-1,2,3: chapas de madeira aglomerada. Rio de Janeiro, 32p., 2002.

\section{ASSOCIAÇÃO BRASILEIRA DE NORMAS}

TÉCNICAS. NBR 14853: madeira: determinação do material solúvel em etanol-tolueno e em diclorometano e em acetona. Rio de Janeiro, 3p., 2010a.

\section{ASSOCIAÇÃO BRASILEIRA DE NORMAS}

TÉCNICAS. NBR 7989: pasta celulósica e madeira: determinação de lignina insolúvel em ácido. Rio de Janeiro, 6p. 2010b.

AZZINI, A.; BENATTI JUNIOR, R.; ARRUDA, M.C.Q. Características tecnológicas dos caules de juta visando a produção de pastas celulósicas para papel. Bragantia, 45(2):249-255, 1986.

BARROS FILHO, R.M. et al. Hybrid chipboard panels based on sugarcane bagasse, urea formaldehyde and melamine formaldehyde resin. Industrial Crops and Products, 33(2):369-373, 2011.

BUFALINO, L. et al. Particleboards made from Australian red cedar: processing variables and evaluation of mixed species. Journal of Tropical Forest Science, 24(2):162-172, 2012.

CABRAL, C.P. et al. Propriedades de chapas de aglomerado confeccionadas com misturas de partículas de Eucalytus spp e Pinus elliottii. Revista Árvore, 31(5):897-905, 2007. 
CABRAL, C.P. et al. Propriedades de chapas tipo OSB, fabricadas com partículas acetiladas de madeiras de Eucalyptus grandis, Eucalyptus urophylla, Eucalyptus cloeziana e Pinus elliottii. Revista Árvore, 30(9):659668, 2006.

COMMERCIAL STANDARD. CS 236-66: mat formed wood particleboard. Geneva, 18p., 1968.

FOOD AND AGRICULTURAL ORGANIZATION OF UNITED NATIONS. Julho de 2013. Disponível em: $<$ http://wwww.fao.org>. Acesso em: 31 jul. 2013.

FENGEL, D.; WEGENER, G. Wood: chemistry, ultrastruture and reactions. Berlin: W. Gruyter, 615p., 1989.

GHAVAMI, K.; TOLEDO FILHO, R.D.

Desenvolvimento de materiais de construção de baixo custo de energia usando fibras naturais, terra e bambu.

Revista Engenharia Agrícola, 1(1):1-19, 1992.

GUIMARÃES JÚNIOR, J.B. et al. Painéis de madeira de eucalipto: estudo de caso de espécie e procedência.

Cerne, 15(1):10-18, 2009.

GUIOTOKU, M. et al. Utilização de palitos de erva-mate na produção de painéis de aglomerado. Colombo: EMBRAPA, 6p., 2008.

GULLICHSEN, J.; PAULAPURO, H. Forest products chemistry. OyHelsinki: Fapet Oy, 350p., 2000.

JOHN, M.J.; ANANDJIWALA, A.D. Recent developments in chemical modification and characterization of natural fiber-reinforced composites. Polymer Composites, 29(2):187-207, 2008.

JOSELEAU, J.P. et al. Detection in situ and characterization of lignin in the G-layer of tension wood fibres of Populus deltoids. Planta, 219(2):338-345, 2004.

KHEDARI, J. et al. New low-cost insulation particleboards from mixture of durian peel and coconut coir. Building and Environment, 39(1):59-65, 2004.

MARRA, A.A. Technology of wood bonding. New York: V. N. Reinhold, 453p., 1992.
MENDES, R.F. et al. Painéis aglomerados produzidos com bagaço de cana em associação com madeira de eucalipto. Scientia Forestalis, 38(86):285-295, 2010.

\section{NORMEM FUR HOLZFASERPLATEN}

SPANPLATTEN SPERRHOLZ. DIN 52362: testing of wood chipboards bending test, determination of bending strength. Berlin, 40p., 1982.

OKINO, E.Y.A. et al. Resistência físicomecânica de chapas aglomeradas de bagaço de cana-de-açucar modificado quimicamente. Sciencia Forestalis, Piracicaba, v.52, p.35-42, 1987.

OKINO, E.Y.A.; ROWELL, R.M. Utilization of Eucalyptus grandis and Pinus taeda from Brazilian plantations to make dimensionally stabilized flakeboard. Ciência e Cultura, 48(4):248-253, 1996.

PIZZI, A. (Ed.). Advanced wood adhesives technology. New York: M. Dekker, 289p., 1994.

REDDY, G.V. et al. Utilization of banana waste for the production of lignolytic and cellulolytic enzymes by solid substrate fermentation using two Pleurotus species (P. ostreatus and P. sajor-caju). Process Biochemistry, 38(10):1457-1462, 2003.

ROJAS, M.L.B. Caracterização de fibras de bananeira Nanicão (Musa Grupo AAA, .Giant Cavendish.) como possível matéria-prima para produção de pasta celulósica para fabricação de papel. São Paulo: Instituto de Pesquisas Tecnológicas do Estado de São Paulo - IPT, 8p. 1996.

SAVASTANO JÚNIOR, H.; PIMENTEL, L.L. Viabilidade do aproveitamento de resíduos de fibras vegetais para fins de obtenção de material de construção. Revista Brasileira de Engenharia Agrícola e Ambiental, 4(1):103-110, 2000.

SELLERS, T.; MCSWEEN JUNIOR, J.R.; NEARN, W.T. Gluing of Eastern hardwoods: a review. New Orleans: Southern Forest Experimental Station, 6p., 1988.

SILVA NETO, S. P. da; GUIMARÃES, T. G. Evolução da cultura da banana no Brasil e no mundo. Planaltina, DF: Embrapa Cerrados, 2011. Disponível em: <http://www.cpac.embrapa.br/noticias/artigosmidia/ publicados/287/>. Acesso em: 05 jan. 2013 
SJÖSTRÖM, E.; ALÉN, R. Analytical methods in wood chemistry, pulping, and papermaking. Berlin: Springer-Verlag, 316p., 1998.

SWEET, M.S.; WINANDY, J.E. The influence of degree of polymerization (DP) of cellulose and hemicellulose on the strength loss of fire-retardant-treated wood.

Holzforschung, 53(3):311-317, 1999.

VITAL, B.R. Métodos de determinação da densidade da madeira. Viçosa, MG: Sociedade de Investigações Florestais, 21p., 1984. 